\title{
CORRELATION OF THE SYSTEMIC AND INTRA-OCULAR EFFECTS OF DIAMOX*
}

\author{
BY \\ DOROTHY A. CAMPBELL, EVA L. TONKS, AND MARY JONES \\ Research Department, Birmingham and Midland Eye Hospital
}

MANY opinions have been expressed in favour of the theory that Diamox causes a fall in intra-ocular pressure by virtue of its local inhibition of carbonic anhydrase within the eye. There has been very little attempt to correlate the ocular effects of Diamox with its extensive systemic action, i.e. in causing diuresis and an increased excretion of electrolytes especially of sodium and potassium, (Counihan, Evans, and Milne, 1954; Hanley and Platts, 1956).

Since water imbibition causes a rise in tension it might well be expected that diuresis would have the reverse effect, and that the loss of sodium, an ion which is intimately associated with the retention of water within the body, might also be expected to favour the loss of extracellular fluid not only from the blood but from the eye.

A single dose of Diamox (250 mg. or more) will produce its systemic effects almost immediately; these last for 24 hours, but on subsequent days or with repeated doses occur to only a slight extent. The patient is left in a state of acidosis which persists after diuresis has ceased (Hofbauer, Kaindl, and Reinhardt, 1955). In the treatment of cardiac oedema (Maren, Wadsworth, Yale, and Alonso, 1954) or of glaucoma, the patient may become resistant to the action of Diamox. Some cases of glaucoma are resistant from the outset. These phenomena are still unexplained.

The cessation of acidosis in the normal subject may take 2 to 4 days after a single dose, and from 5 to 7 days after repeated doses (Hanley and Platts, 1956). One should therefore consider whether it is desirable to use repeated doses in the treatment of glaucoma or whether Diamox would be more wisely employed in single doses at intervals of several days with miotics in the interim. Hofbauer and others (1955) have found that this is the most efficacious form of therapy in cases of cardiac oedema, and recommend its use for a period of three successive days at the most.

Langham (1955) reports that, although the concentration of bicarbonate in the aqueous is diminished after the administration of Diamox, its concentration relative to that in the plasma is unchanged; Gloster and Perkins (1955), from their records of the fall in intra-ocular pressure after intravenous Diamox, consider that the rapidity of its action should not be accepted as proof of a local effect upon the eye.

-Received for publication February 6, 1956. 
In a preliminary communication, one of us (Campbell, 1955) reported that the fall in intra-ocular pressure is synchronized with a considerable fall in the level of blood sodium and with the onset of diuresis and of increased electrolyte excretion.

We have investigated these changes more fully in individual patients in the hope of elucidating the relationship between the systemic and intra-ocular effects.

\section{Experimental Procedure}

In the present series of experiments we have followed the effects of a single dose of $250 \mathrm{mg}$. Diamox, by taking simultaneous records of intra-ocular pressure, of the amount and rate of diuresis, and of the variation of sodium and potassium in the blood and urine.
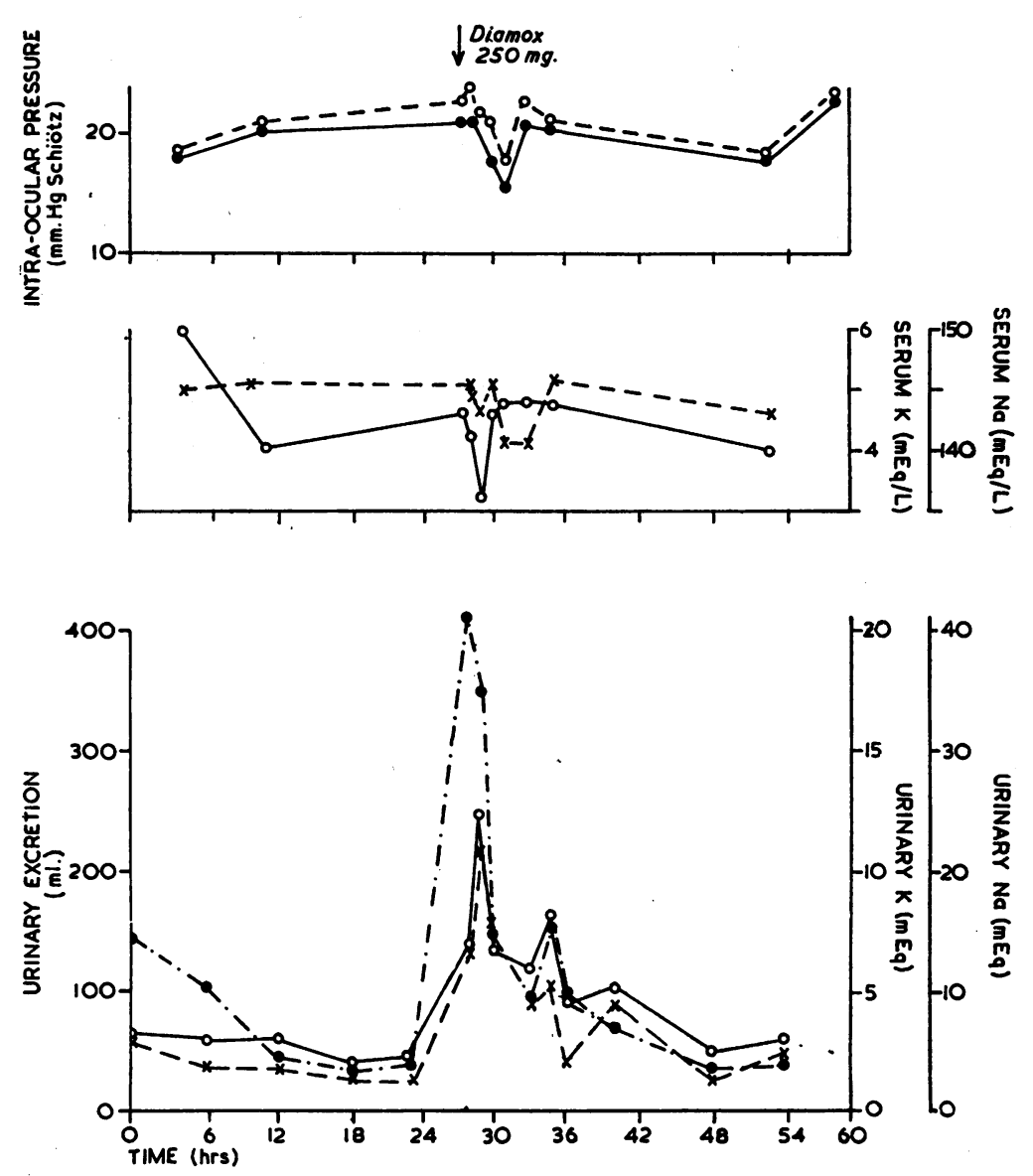

URINE : $\bullet-\rightarrow$ Volume $\multimap$ Sodium $\quad x-\rightarrow$ Potossium

FIG. 1.-Effects of $250 \mathrm{mg}$. Diamox, in a normal subject (Case 14), on intraocular pressure, serum sodium and potassium levels, and urinary sodium and potassium levels. 
Each subject was investigated as an in-patient, in bed, in the Research Department, his or her co-operation and interest being secured by interview on admission.

Since our aim was to check the action of Diamox as used clinically, the patient was allowed routine hospital meals at specified hours. The diet was uniform and so chosen that its salt content did not exceed $44 \mathrm{mEq}$ sodium in 24 hours, of which approximately $6 \mathrm{mEq}$ was taken at breakfast, 10 at lunch, and 5 at tea. The water intake was strictly controlled with a view to maintaining the patient in a state of regular hydration. The same routine was followed for 3 days, breakfast of toast, butter, and marmalade, and $5 \mathrm{oz}$. water being given at 7 a.m., followed by . 5 oz. water at each hour from 9 a.m. to 12 noon when lunch was served; $10 \mathrm{oz}$. very weak tea were allowed at $3 \mathrm{p} . \mathrm{m}$. with a little bread and butter. The period of detailed observation ended at 5 p.m. During the evening and night the fluid intake was also controlled, but there was a variation of $100-200 \mathrm{ml}$. in the total consumption of fluid in individual subjects.

During the first and third days urine was collected at 6-hrly intervals, samples of blood and records of intra-ocular pressure being taken at 10 a.m. and 4 p.m.
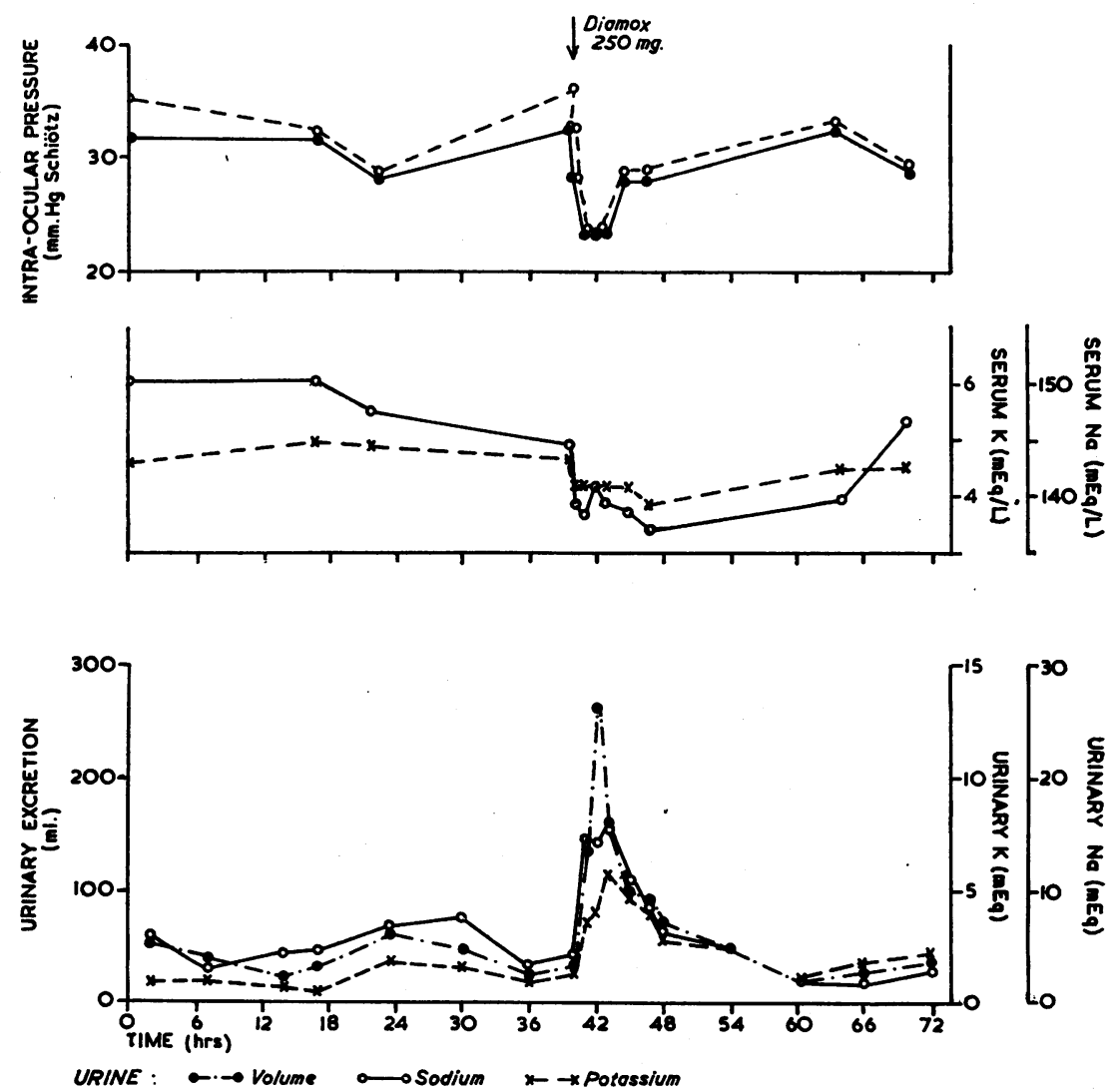

Fig. 2.-Effects of $250 \mathrm{mg}$. Diamox, in a subject with active glaucoma (Case 5), on intra-ocular pressure, serum sodium and potassium levels, and urinary sodium and potassium levels. 
On the second day urine was collected for the period 6-10 a.m. A sample of blood and the intra-ocular pressure were taken at a few minutes before 10 a.m., at which hour $250 \mathrm{mg}$. Diamox was given. Samples of blood and of urine, and intra-ocular pressure readings were taken at frequent intervals until 5 p.m.

Methods of Estimation.-Sodium and potassium were estimated by the E.E.L. flame photometer, the error of estimation being \pm 1.0 per cent.

Intra-ocular pressure was measured by a weighted Schiötz tonometer which had been calibrated.

Material.-Five normal subjects (Group C) and nine cases of glaucoma were investigated. The latter were divided into "active" (Group A), in which the initial intra-ocular pressure was over $26 \mathrm{~mm}$. $\mathrm{Hg}$, and " quiescent" (Group B), in which the pressure was above $26 \mathrm{~mm}$. $\mathrm{Hg}$ on admission, but fell to this level or below after 2 days' rest in bed (Figs 1 and 2 ).

TABLE I

CHANGES IN INTRA-OCULAR PRESSURE AFTER $250 \mathrm{mg}$. DIAMOX

\begin{tabular}{|c|c|c|c|c|c|c|c|c|c|c|c|c|c|}
\hline \multirow{2}{*}{ Time (Hrs) } & & & \multicolumn{10}{|c|}{ Intra-Ocular Pressure (mm. $\mathbf{H g})$} & \multirow{2}{*}{$\begin{array}{c}\text { Type of } \\
\text { Glaucoma }\end{array}$} \\
\hline & & & 0 & $\frac{1}{4}$ & $\frac{1}{2}$ & $\frac{3}{4}$ & 1 & 2 & 3 & 4 & 5 & 7 & \\
\hline \multirow{6}{*}{$\begin{array}{l}\text { A) Active } \\
\text { Glaucoma } \\
\text { (Initial } \\
\text { intra-ocular } \\
\text { pressure } \\
\text { above } \\
26 \mathrm{~mm} . \mathbf{H g} \text { ) }\end{array}$} & \multirow{5}{*}{$\begin{array}{l}\text { Case } \\
\text { No. }\end{array}$} & $1 T\{$ & $\begin{array}{l}35 \\
32\end{array}$ & 二 & $\begin{array}{l}40 \\
35\end{array}$ & $\overline{-}$ & $\begin{array}{l}35 \\
30\end{array}$ & $\begin{array}{l}30 \\
26\end{array}$ & $\begin{array}{l}26 \\
26\end{array}$ & 二 & $\begin{array}{l}30 \\
30\end{array}$ & $\begin{array}{l}28 \\
28\end{array}$ & \} $\begin{array}{c}\text { Conges- } \\
\text { tive }\end{array}$ \\
\hline & & 2\{ & $\begin{array}{l}30 \\
27\end{array}$ & $\begin{array}{l}30 \\
23\end{array}$ & $\begin{array}{l}27 \\
20\end{array}$ & $\begin{array}{l}23 \\
20\end{array}$ & $\begin{array}{l}20 \\
18\end{array}$ & $\begin{array}{l}18 \\
15\end{array}$ & $\begin{array}{l}18 \\
15\end{array}$ & 二 & 18 & 18 & Simplex \\
\hline & & 3 I \{ & $\begin{array}{l}35 \\
30\end{array}$ & $\begin{array}{l}28 \\
30\end{array}$ & $\begin{array}{l}28 \\
30\end{array}$ & $\begin{array}{l}23 \\
28\end{array}$ & $\begin{array}{l}23 \\
30\end{array}$ & 二 & - & 二 & $\begin{array}{l}35 \\
30\end{array}$ & $\begin{array}{l}35 \\
30\end{array}$ & Simplex \\
\hline & & $4 T\{$ & $\begin{array}{l}35 \\
35\end{array}$ & $\begin{array}{l}40 \\
40\end{array}$ & $\begin{array}{l}30 \\
35\end{array}$ & $\begin{array}{l}28 \\
30\end{array}$ & $\begin{array}{l}28 \\
28\end{array}$ & $\begin{array}{l}20 \\
20\end{array}$ & $\begin{array}{l}20 \\
20\end{array}$ & - & $\begin{array}{l}20 \\
23\end{array}$ & $\begin{array}{l}23 \\
25\end{array}$ & \} $\begin{array}{c}\text { Conges- } \\
\text { tive }\end{array}$ \\
\hline & & 5\{ & $\begin{array}{l}35 \\
32\end{array}$ & $\begin{array}{l}32 \\
28\end{array}$ & $\begin{array}{l}32 \\
28\end{array}$ & 二 & $\begin{array}{l}28 \\
23\end{array}$ & $\begin{array}{l}23 \\
23\end{array}$ & $\begin{array}{l}23 \\
23\end{array}$ & - & $\begin{array}{l}28 \\
28\end{array}$ & $\begin{array}{l}28 \\
28\end{array}$ & Simplex \\
\hline & \multicolumn{2}{|c|}{ Average } & $32 \cdot 6$ & $31 \cdot 4$ & $30 \cdot 0$ & $25 \cdot 3$ & $25 \cdot 8$ & $21 \cdot 9$ & $21 \cdot 4$ & - & $26 \cdot 9$ & 27 & - \\
\hline \multirow{5}{*}{$\begin{array}{l}\text { (B) Quiescent } \\
\text { Glaucoma } \\
\text { (Initial } \\
\text { intra-ocular } \\
\text { pressure } \\
26 \mathrm{~mm} \text {. } \mathrm{Hg} \\
\text { or less) }\end{array}$} & \multirow{4}{*}{$\begin{array}{l}\text { Case } \\
\text { No. }\end{array}$} & 6 & $\begin{array}{l}26 \\
26\end{array}$ & 二 & $\begin{array}{l}26 \\
23\end{array}$ & 二 & $\begin{array}{l}26 \\
26\end{array}$ & $\begin{array}{l}21 \\
20\end{array}$ & $\begin{array}{l}17 \\
17\end{array}$ & $\begin{array}{l}17 \\
15\end{array}$ & $\begin{array}{l}20 \\
20\end{array}$ & $\begin{array}{l}20 \\
20\end{array}$ & Simplex \\
\hline & & $7 \mathbf{T}\{$ & $\begin{array}{l}22 \\
18\end{array}$ & - & $\begin{array}{l}26 \\
20\end{array}$ & 二 & $\begin{array}{l}21 \\
18\end{array}$ & $\begin{array}{l}28 \\
21\end{array}$ & $\begin{array}{l}21 \\
16\end{array}$ & 二 & $\begin{array}{l}20 \\
15\end{array}$ & $\begin{array}{l}23 \\
16\end{array}$ & \} Simplex \\
\hline & & $8 \mathrm{~T}\{$ & $\begin{array}{l}20 \\
15\end{array}$ & - & $\begin{array}{l}20 \\
13\end{array}$ & - & $\begin{array}{l}20 \\
13\end{array}$ & $\begin{array}{l}17 \\
13\end{array}$ & $\begin{array}{l}17 \\
13\end{array}$ & $\begin{array}{l}15 \\
13\end{array}$ & $\begin{array}{l}17 \\
13\end{array}$ & $\begin{array}{l}17 \\
13\end{array}$ & \} Simplex \\
\hline & & $9 \begin{array}{ll}\mathbf{T} \\
\mathrm{T}\end{array}$ & $\begin{array}{l}26 \\
18\end{array}$ & - & $\begin{array}{l}30 \\
20\end{array}$ & - & $\begin{array}{l}26 \\
22\end{array}$ & $\begin{array}{l}22 \\
15\end{array}$ & $\begin{array}{l}22 \\
17\end{array}$ & $\begin{array}{l}22 \\
17\end{array}$ & $\begin{array}{l}22 \\
17\end{array}$ & $\begin{array}{l}22 \\
15\end{array}$ & \} Simplex \\
\hline & \multicolumn{2}{|c|}{ Average } & $21 \cdot 4$ & - & $22 \cdot 2$ & - & $21 \cdot 5$ & $19 \cdot 6$ & $17 \cdot 5$ & $16 \cdot 5$ & 18 & $18 \cdot 2$ & - \\
\hline \multirow{6}{*}{$\begin{array}{l}\text { (C) Normal } \\
\text { Subjects }\end{array}$} & \multirow{5}{*}{$\begin{array}{l}\text { Case } \\
\text { No. }\end{array}$} & 10 & $\begin{array}{l}20 \\
20\end{array}$ & $\begin{array}{l}20 \\
20\end{array}$ & $\begin{array}{l}20 \\
20\end{array}$ & $\begin{array}{l}18 \\
18\end{array}$ & $\begin{array}{l}15 \\
15\end{array}$ & $\begin{array}{l}11 \\
11\end{array}$ & $\begin{array}{l}8 \\
8\end{array}$ & - & 11 & 15 & \\
\hline & & 11 & $\begin{array}{l}20 \\
20\end{array}$ & 二 & $\begin{array}{l}18 \\
18\end{array}$ & - & $\begin{array}{l}18 \\
18\end{array}$ & $\begin{array}{l}13 \\
13\end{array}$ & $\begin{array}{l}15 \\
12\end{array}$ & - & $\begin{array}{l}15 \\
15\end{array}$ & $\begin{array}{l}17 \\
17\end{array}$ & \\
\hline & & 12 & $\begin{array}{l}20 \\
22\end{array}$ & - & $\begin{array}{l}15 \\
20\end{array}$ & - & $\begin{array}{l}15 \\
15\end{array}$ & $\begin{array}{l}23 \\
20\end{array}$ & $\begin{array}{l}20 \\
17\end{array}$ & - & $\begin{array}{l}17 \\
13\end{array}$ & $\begin{array}{l}20 \\
15\end{array}$ & \\
\hline & & 13\{ & $\begin{array}{l}16 \\
16\end{array}$ & 二 & $\begin{array}{l}16 \\
16\end{array}$ & - & $\begin{array}{l}16 \\
16\end{array}$ & $\begin{array}{l}16 \\
16\end{array}$ & $\begin{array}{l}18 \\
18\end{array}$ & 二 & $\begin{array}{l}12 \\
12\end{array}$ & $\begin{array}{l}20 \\
20\end{array}$ & \\
\hline & & 14\{ & $\begin{array}{l}20 \\
22\end{array}$ & - & $\begin{array}{l}20 \\
23\end{array}$ & 二 & $\begin{array}{l}19 \\
21\end{array}$ & $\begin{array}{l}17 \\
20\end{array}$ & $\begin{array}{l}15 \\
18\end{array}$ & 二 & $\begin{array}{l}20 \\
22\end{array}$ & $\begin{array}{l}20 \\
20\end{array}$ & \\
\hline & \multicolumn{2}{|c|}{ Average } & $19 \cdot 6$ & - & $18 \cdot 6$ & - & $17 \cdot 7$ & $16 \cdot 0$ & $14 \cdot 9$ & - & $14 \cdot 8$ & $18 \cdot 2$ & \\
\hline
\end{tabular}

$T=$ Non-functioning trephined eye.

$\mathrm{I}=$ Non-functioning eye after iridectomy. 


\section{Results}

Intra-Ocular Pressure (Table I).-The variations in intra-ocular pressure were closely alike in each pair of eyes, even when one of the pair was a trephined eye (Fig. 3).

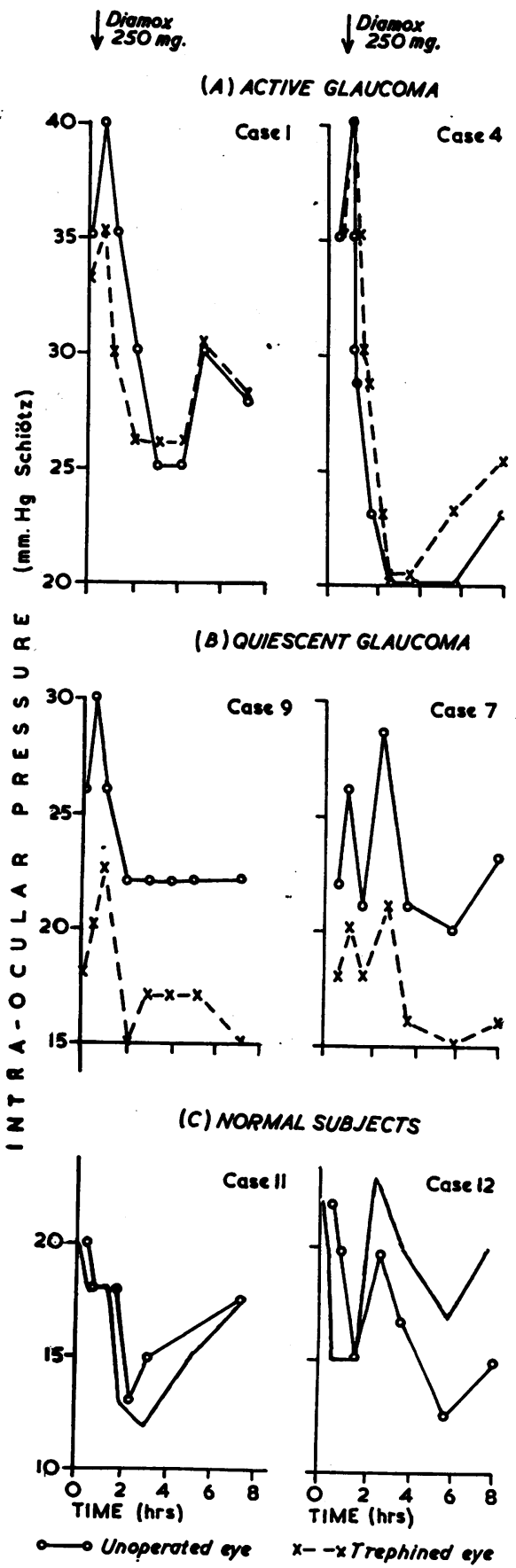

Fig. 3.-Comparison of the effects of $250 \mathrm{mg}$. Diamox on intra-ocular pressure in the two eyes of: (A) two subjects with active glaucoma (Cases 1 and 4), (B) two subjects with quiescent glaucoma (Cases 9 and 7), (C) two normal subjects (Cases 11 and 12). 
There were considerable differences between individual subjects, but the average maximum fall observed in the 7-hr. period after Diamox (Fig. 4) was $4.8 \mathrm{~mm} . \mathrm{Hg}$ in normal subjects, $11.2 \mathrm{~mm}$. $\mathrm{Hg}$. in active glaucoma, and $4.9 \mathrm{~mm} . \mathrm{Hg}$ in quiescent glaucoma.

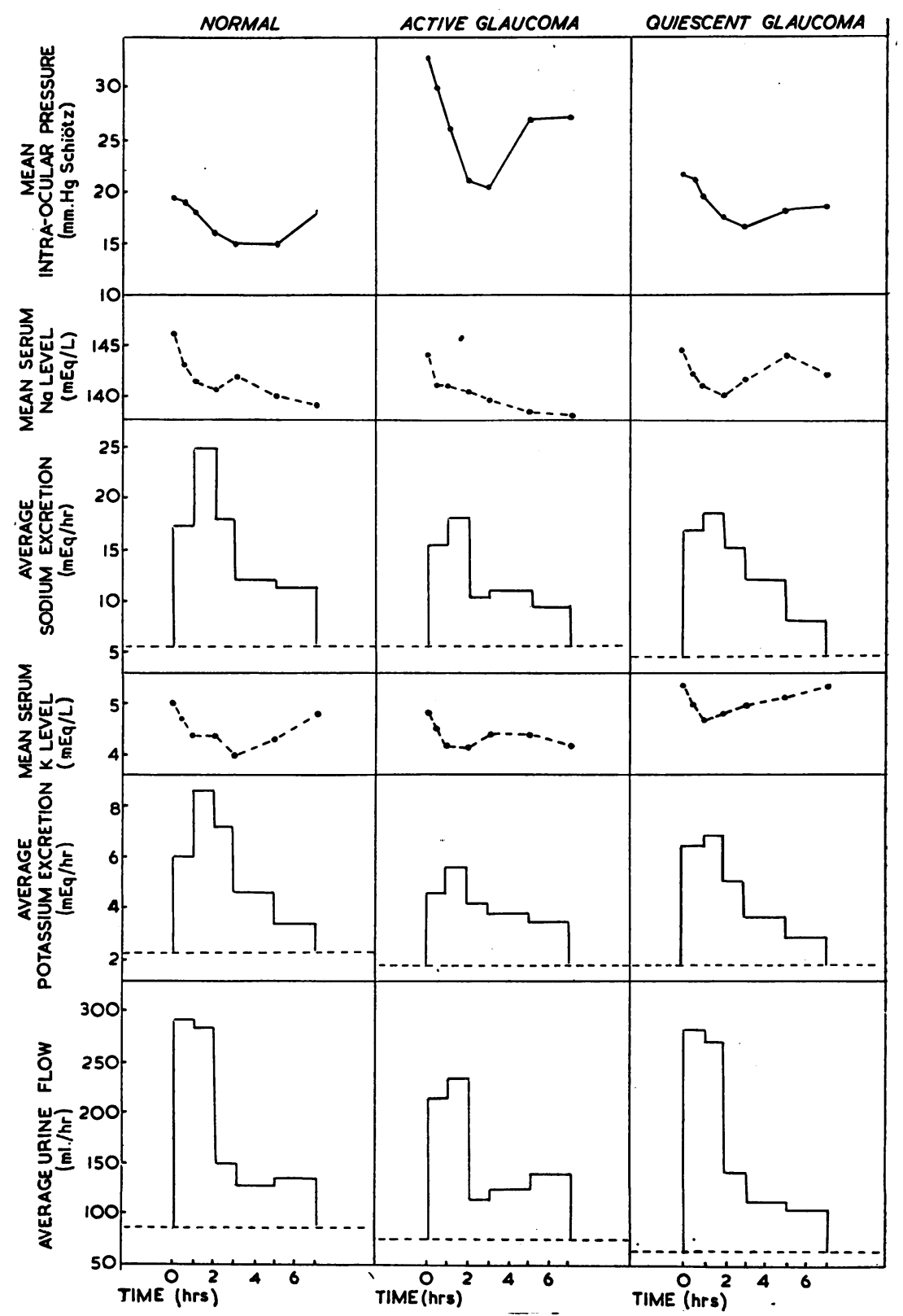

FIG. 4.-Comparison of changes in intra-ocular pressure, serum sodium and potassium levels, and urinary sodium and potassium levels after $250 \mathrm{mg}$. Diamox in normal subjects, and in subjects with active and quiescent glaucoma.

Dotted base-line shows rate of excretion in 4-hr period before injection of Diamox. 
This occurred within 3 to $4 \mathrm{hrs}$, and then the intra-ocular pressure began to rise. In the majority of glaucomatous subjects it did not regain its initial level for 20 to $24 \mathrm{hrs}$, whereas in normal subjects it did so in 7 to $8 \mathrm{hrs}$.

Five cases $(1,2,7,9$, and 14) shewed a small initial rise in the first half-hour similar to that observed by Gloster and Perkins (1955) in the rabbit after the intravenous administration of Diamox.

Serum Sodium (Table II).-On the average results there was an immediate fall in the level of serum sodium which coincided for the first $2 \mathrm{hrs}$ with the fall in intra-ocular pressure. In normal subjects and those with quiescent glaucoma, the serum sodium then shewed a rise followed by a secondary fall in 3 to 5 hrs (Fig. 4). In the majority of cases of active glaucoma the serum sodium fell steadily for $7 \mathrm{hrs}$ and remained below its initial level for about $30 \mathrm{hrs}$ (Fig. 2).

TABLE II

CHANGES IN SERUM SODIUM AFTER DIAMOX

\begin{tabular}{|c|c|c|c|c|c|c|c|c|c|}
\hline \multirow{2}{*}{\multicolumn{3}{|c|}{ Time (hrs) }} & \multicolumn{7}{|c|}{ Serum Sodium (mEq./L) } \\
\hline & & & 0 & $\frac{1}{2}$ & 1 & 2 & 3 & 5 & 7 \\
\hline \multirow{6}{*}{ (A) Active } & \multirow{5}{*}{ Case No. } & 1 & 148 & 151 & 151 & 148 & 144 & 144 & 142 \\
\hline & & 2 & 141 & 137 & 144 & 144 & 143 & 139 & 137 \\
\hline & & 3 & 144 & 139 & 135 & 133 & 137 & 135 & 139 \\
\hline & & 4 & 144 & 142 & 139 & 137 & 136 & 137 & 137 \\
\hline & & 5 & 144 & 139 & 138 & 140 & 139 & 138 & 137 \\
\hline & \multicolumn{2}{|c|}{ Average } & $144 \cdot 2$ & $141 \cdot 2$ & $141 \cdot 4$ & $140 \cdot 4$ & $139 \cdot 8$ & $138 \cdot 6$ & $138 \cdot 4$ \\
\hline \multirow{5}{*}{ (B) Quiescent } & \multirow{4}{*}{ Case No. } & 6 & 144 & 144 & 144 & 137 & 141 & 141 & 147 \\
\hline & & 7 & 147 & 144 & 139 & 142 & 140 & 144 & 138 \\
\hline & & 8 & 144 & 144 & 143 & 144 & 144 & 148 & 144 \\
\hline & & 9 & 144 & 141 & 141 & 140 & 143 & 144 & 138 \\
\hline & \multicolumn{2}{|c|}{ Average } & $144 \cdot 7$ & $143 \cdot 2$ & $141 \cdot 7$ & $140 \cdot 7$ & $142 \cdot 0$ & $144 \cdot 2$ & $141 \cdot 7$ \\
\hline \multirow{6}{*}{ (C) Normal } & \multirow{5}{*}{ Case No. } & 10 & 146 & 139 & 137 & 135 & 137 & 133 & 139 \\
\hline & & 11 & 144 & 144 & 141 & 138 & 143 & 137 & 138 \\
\hline & & 12 & 147 & 147 & 147 & 144 & 143 & 141 & 136 \\
\hline & & 13 & 151 & 146 & 146 & 144 & 142 & 146 & 140 \\
\hline & & 14 & 143 & 141 & 136 & 143 & 144 & 144 & 144 \\
\hline & \multicolumn{2}{|c|}{ Average } & $146 \cdot 2$ & $143 \cdot 4$ & $141 \cdot 4$ & $140 \cdot 8$ & $141 \cdot 8$ & $140 \cdot 2$ & $139 \cdot 4$ \\
\hline
\end{tabular}

One resistant case of quiescent glaucoma (Case 8) shewed virtually no initial fall in the level of serum sodium and a subsequent large rise; she 
excreted very little sodium or urine and had only a slight fall in intra-ocular pressure (Fig. 5, opposite). The same phenomena were observed in an additional patient (Case 15) not included in the series, who became almost hysterical during the test (Fig. 6, opposite).

Serum Potassium (Table III).-The changes in serum potassium, although of much less significance osmotically, were nevertheless appreciable. In all but one subject there was an initial fall during the first $2 \mathrm{hrs}$ in all three groups which *was usually followed by a rise. This rise was sustained up to the end of the 7-hr period in normal subjects and in quiescent glaucoma, but the active glaucoma cases shewed a fall in the last 2 hrs (Fig. 4).

TABLE III

CHANGES IN SERUM POTASSIUM AFTER DIAMOX

\begin{tabular}{|c|c|c|c|c|c|c|c|c|c|}
\hline \multirow{2}{*}{\multicolumn{3}{|c|}{ Time (hrs) }} & \multicolumn{7}{|c|}{ Serum Potassium (mEq./L) } \\
\hline & & & 0 & $\frac{1}{2}$ & 1 & 2 & 3 & 5 & 7 \\
\hline \multirow{6}{*}{ (A) Active } & \multirow{5}{*}{ Case No. } & 1 & $4 \cdot 9$ & $5 \cdot 6$ & $5 \cdot 4$ & $5 \cdot 6$ & $5 \cdot 4$ & $5 \cdot 1$ & $4 \cdot 4$ \\
\hline & & 2 & $4 \cdot 9$ & $3 \cdot 8$ & $3 \cdot 8$ & $3 \cdot 8^{\circ}$ & $4 \cdot 1$ & $4 \cdot 4$ & $4 \cdot 1$ \\
\hline & & 3 & $4 \cdot 9$ & $4 \cdot 6$ & $4 \cdot 1$ & $3 \cdot 8$ & $4 \cdot 4$ & $4 \cdot 4$ & $4 \cdot 4$ \\
\hline & & 4 & $4 \cdot 6$ & $4 \cdot 4$ & $4 \cdot 1$ & $3 \cdot 8$ & $3 \cdot 8$ & $3 \cdot 8$ & $4 \cdot 1$ \\
\hline & & 5 & $4 \cdot 6$ & $4 \cdot 1$ & $4 \cdot 1$ & $4 \cdot 1$ & $4 \cdot 1$ & $4 \cdot 1$ & $3 \cdot 8$ \\
\hline & \multicolumn{2}{|c|}{ Average } & $4 \cdot 8$ & $4 \cdot 5$ & $4 \cdot 3$ & $4 \cdot 2$ & $4 \cdot 4$ & $4 \cdot 4$ & $4 \cdot 2$ \\
\hline \multirow{5}{*}{ (B) Quiescent } & \multirow{4}{*}{ Case No. } & 6 & - & - & - & 一 & - & - & 一 \\
\hline & & 7 & $5 \cdot 4$ & $5 \cdot 6$ & $4 \cdot 9$ & $4 \cdot 6$ & $4 \cdot 6$ & $4 \cdot 9$ & $4 \cdot 9$ \\
\hline & & 8 & $5 \cdot 6$ & $5 \cdot 1$ & $4 \cdot 9$ & $5 \cdot 1$ & $5 \cdot 6$ & $5 \cdot 6$ & $5 \cdot 6$ \\
\hline & & 9 & $5 \cdot 1$ & $4 \cdot 4$ & $4 \cdot 4$ & $4 \cdot 6$ & $4 \cdot 9$ & $5 \cdot 1$ & $5 \cdot 6$ \\
\hline & \multicolumn{2}{|c|}{ Average } & $5 \cdot 4$ & $5 \cdot 0$ & $4 \cdot 7$ & $4 \cdot 8$ & $5 \cdot 0$ & $5 \cdot 2$ & $5 \cdot 4$ \\
\hline \multirow{6}{*}{ (C) Normal } & \multirow{5}{*}{ Case No. } & 10 & $4 \cdot 6$ & $4 \cdot 6$ & $4 \cdot 1$ & $3 \cdot 8$ & $3 \cdot 8$ & $4 \cdot 1$ & $4 \cdot 1$ \\
\hline & & 11 & $4 \cdot 9$ & $4 \cdot 6$ & $4 \cdot 4$ & $4 \cdot 1$ & $3 \cdot 8$ & $4 \cdot 9$ & $4 \cdot 6$ \\
\hline & & 12 & $4 \cdot 9$ & $4 \cdot 9$ & $4 \cdot 6$ & $4 \cdot 4$ & $4 \cdot 1$ & $4 \cdot 1$ & $5 \cdot 6$ \\
\hline & & 13 & $4 \cdot 9$ & $4 \cdot 4$ & $4 \cdot 4$ & $4 \cdot 4$ & $4 \cdot 1$ & $4 \cdot 4$ & $4 \cdot 6$ \\
\hline & & 14 & $5 \cdot 1$ & $4 \cdot 9$ & $4 \cdot 6$ & $5 \cdot 1$ & $4 \cdot 1$ & $4 \cdot 1$ & $5 \cdot 1$ \\
\hline & \multicolumn{2}{|c|}{ Average } & $4 \cdot 9$ & $4 \cdot 7$ & $4 \cdot 4$ & $4 \cdot 4$ & $4 \cdot 0$ & $4 \cdot 3$ & $4 \cdot 8$ \\
\hline
\end{tabular}

Excretion

(a) Urinary Output.-The period of maximum output occurred during the first $2 \mathrm{hrs}$, and coincided in all subjects with the period of maximum fall in intra-ocular pressure. In active glaucoma cases the increase in urine flow 
was noticeably less and the fall in intra-ocular pressure was greater during this period than in the other two groups (Fig. 4). Cases 5, 8 (Fig. 5), and 15 (Fig. 6) with a small diuresis shewed very little fall in intra-ocular pressure.
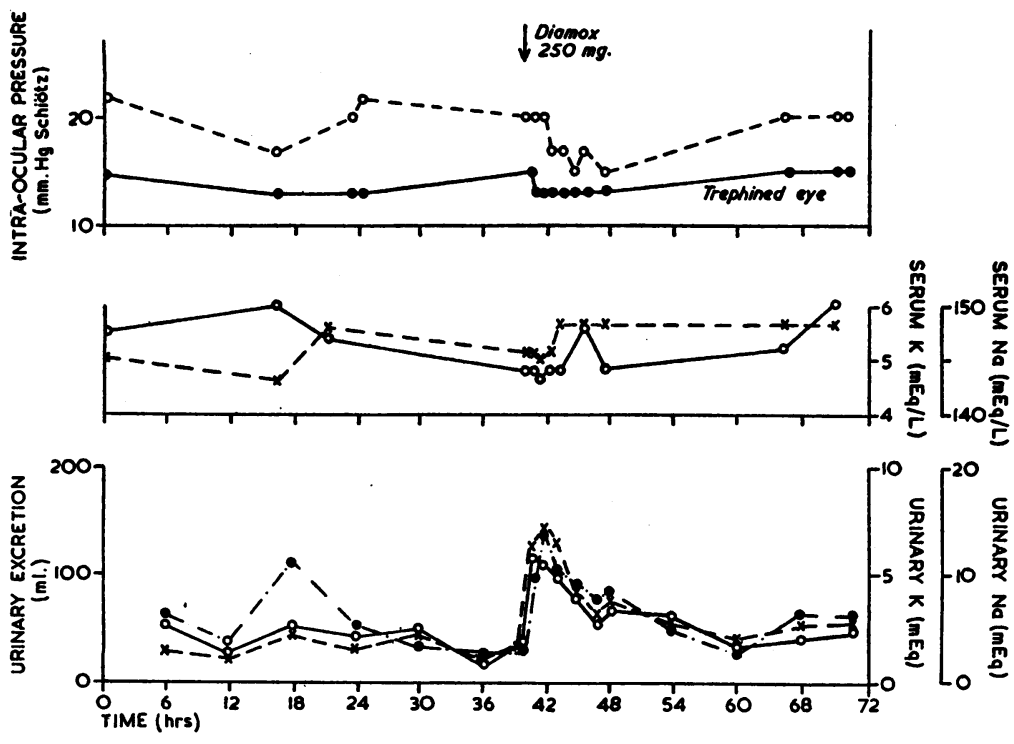

Fig. 5-Resistance to Diamox $250 \mathrm{mg}$. in a subject with quiescent glaucoma (Case 8), showing intra-ocular pressure, serum sodium and potassium levels, and urinary sodium and potassium levels.

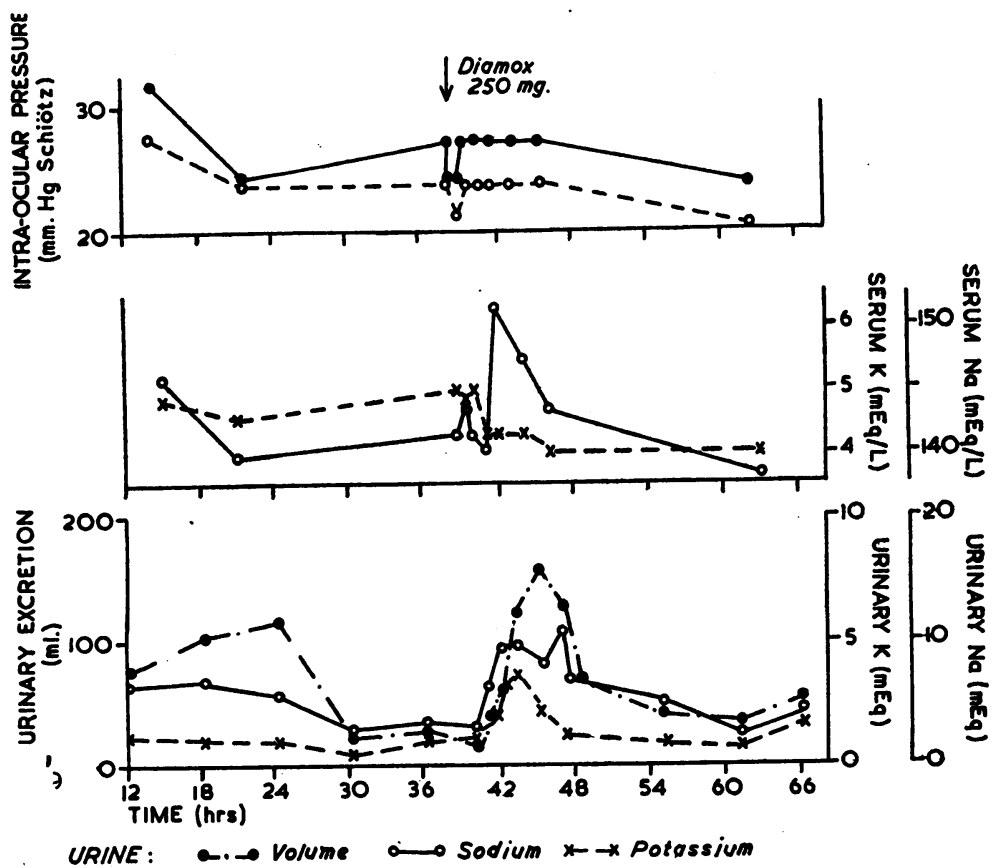

Fig. 6.-Effect of emotion on results of Diamox test in Case 15. 
(b) Output of Sodium and Potassium.-The excretion of these electrolytes was at a maximum during the second hour, the rate of excretion and total output in $7 \mathrm{hrs}$ being less in glaucomatous subjects than in normals (Fig. 4).

The true increase in excretion caused by Diamox over the "expected rate" can be shewn by deducting the output of the control day from that of the test day for the same time period (viz. 10 a.m. to 5 p.m.). A comparison of the cumulative excretion of urine and of electrolytes in the three groups of subjects shews that the increase in $\mathrm{Na}^{+}$output is again noticeably lower in glaucomatous subjects throughout the test (Table IV).

TABLE IV

*CUMULATIVE INCREASE IN URINARY OUTPUT DUE TO $250 \mathrm{mg}$. DIAMOX

\begin{tabular}{|c|c|c|c|c|}
\hline \multirow{2}{*}{\multicolumn{2}{|c|}{ Subjects }} & \multirow{3}{*}{$\begin{array}{c}\text { Normal } \\
190\end{array}$} & \multicolumn{2}{|c|}{ Glaucoma } \\
\hline & & & Active & Quiescent \\
\hline \multirow{3}{*}{ Urine Flow (ml.) } & $1 \mathrm{hr}$ & & 141 & 198 \\
\hline & $2 \mathrm{hrs}$ & 401 & 328 & 374 \\
\hline & $7 \mathrm{hrs}$ & 641 & 566 & 669 \\
\hline \multirow{3}{*}{$\mathrm{Na}+$ Output (mEq.) } & $1 \mathrm{hr}$ & 15 & 9 & 14 \\
\hline & $2 \mathrm{hrs}$ & 38 & 18 & 25 \\
\hline & $7 \mathrm{hrs}$ & 80 & 51 & 61 \\
\hline \multirow{3}{*}{$\mathrm{K}+$ Output (mEq.) } & $1 \mathrm{hr}$ & $4 \cdot 7$ & $2 \cdot 8$ & $4 \cdot 6$ \\
\hline & $2 \mathrm{hrs}$ & $11 \cdot 7$ & $6 \cdot 4$ & $9 \cdot 3$ \\
\hline & $7 \mathrm{hrs}$ & 20 & 16 & 20 \\
\hline
\end{tabular}

${ }^{*}$ Average for each group of subjects.

\section{Discussion}

Our results show that, whereas there is a variation in the degree of fall of intra-ocular pressure as between one subject and another after a single dose of Diamox, the response in each eye of any particular subject is remarkably alike, even when one eye had been trephined.

Although the maximum fall in intra-ocular pressure observed in active glaucoma is greater than in quiescent glaucoma or in normal subjects, the percentage fall is of the same order in all three groups. Furthermore it coincides with the period of maximum increase in the urinary output of water and of electrolytes $\left(\mathrm{Na}^{+}\right.$and $\left.\mathrm{K}^{+}\right)$, and with a fall in the level of serum sodium.

These facts suggest that the fluctuations of intra-ocular pressure which occur may be an intrinsic part of the osmotic changes which affect the body as a whole, and that any speculation as to the mode of action of Diamox upon the eye should therefore allow for the systemic effects of the drug. 
Our findings concerning the effect of Diamox on urinary excretion confirm those of Lepri and Andreani (1955) who observed a similar diuresis in both normal and glaucomatous patients, but are contrary to those of Leydhecker and Helferich (1955) who found that after a dose of Diamox the minimum intra-ocular pressure was reached before the onset of diuresis, the volume excreted after $750 \mathrm{mg}$. Diamox being only $100-150 \mathrm{ml}$. in the first $3 \mathrm{hrs}$.

In our cases, after $250 \mathrm{mg}$. Diamox, the least individual output was never less than $300 \mathrm{ml}$. during this period, the average for all the glaucomatous cases being $610 \mathrm{ml}$. as opposed to $721 \mathrm{ml}$. for normal subjects.

In several of our glaucoma subjects the fall in intra-ocular pressure was actually commensurate with the volume of urinary output.

In two cases of quiescent glaucoma a very small output of urine and of electrolytes was accompanied by a correspondingly small decrease in intraocular pressure, while this phenomenon was also seen in the hysterical subject (Case 15), in whom antidiuretic factors arising from emotion may well have overcome the systemic effects of Diamox.

One might conclude from these observations that the loss of an appreciable volume of body fluid alone would account for a coincident fall in intra-ocular pressure, particularly in view of the fact that the imbibition of a similar amount of water (now in use as a provocative test for glaucoma) will so readily promote a rise in intra-ocular pressure.

But Becker (1955) has shown that Diamox will still bring about a fall in intra-ocular pressure within $2 \mathrm{hrs}$ in nephrectomized rabbits. Although the responses of such animals may not bear a close resemblance to those of human beings with normal renal function, his experiments suggest that the fall in intra-oculal pressure is not the direct outcome of increased urinary output, but it may nevertheless be associated with changes in the distribution of fluid and of electrolytes within the body.

In the human subject on a controlled intake of water and sodium it is possible to gain some idea whether such changes occur by comparing the progressive alteration in composition of the blood and of the urine.

The blood may be considered to be an integral part of the extracellular fluid (E.C.F.) of the body. If the initial volume of E.C.F. is taken as $15 \mathrm{~L}$, its initial sodium content will be $15 x$-the initial level of serum sodium. In any ensuing period (e.g. in $1 \mathrm{hr}$., $2 \mathrm{hrs}$, and $7 \mathrm{hrs}$ ) it is possible to estimate the resultant concentration of sodium in the E.C.F. by a calculation based on the actual intake and output of water and sodium during the period.

Two examples are given in Table V (overleaf), which shows that, whereas the estimated level of E.C.F. $\mathrm{Na}^{+}$remains remarkably constant, the level of serum $\mathrm{Na}^{+}$, as found by analysis by the flame photometer, shows a fall. This was the case in each individual subject, whether normal or glaucomatous. The degree of fall is outside the experimental error and is larger, in both normal and glaucomatous subjects, than any diurnal variation. It suggests that an alteration occurs in the E.C.F., which is due either to the loss of sodium, or more probably to the gain of water from the intracellular fluid. 
TABLE V

COMPARISON OF ESTIMATED CHANGE IN E.C.F. SODNUM WITH ACTUAL SERUM SODIUM

\begin{tabular}{|c|c|c|c|c|c|}
\hline Subject & $\begin{array}{l}\text { Time } \\
\text { (hrs) }\end{array}$ & $\begin{array}{l}\text { E.C.F. } \\
\text { Volume (L) }\end{array}$ & $\underset{\mathrm{Na}^{+}}{\text {E.C.FEq. }}$ & $\begin{array}{c}\text { Estimated } \\
\text { (Na+) } \\
\text { E.C.F. } \\
(\mathrm{mEq} . / \mathrm{L})\end{array}$ & $\begin{array}{c}\text { Actual } \\
\left(\mathrm{Na}^{+}\right) \\
\text {Serum } \\
(\mathrm{mEq} . / \mathrm{L})\end{array}$ \\
\hline \multirow{4}{*}{$\begin{array}{l}\text { (A) Normal } \\
\text { (Case 10) }\end{array}$} & 0 & $15 \cdot 00$ & 2190 & $146 \cdot 0$ & $146 \cdot 0$ \\
\hline & 1 & $14 \cdot 85$ & 2169 & $146 \cdot 1$ & $137 \cdot 0$ \\
\hline & 2 & $14 \cdot 75$ & 2150 & $145 \cdot 8$ & $135 \cdot 0$ \\
\hline & 7 & $14 \cdot 40$ & 2111 & $146 \cdot 5$ & $139 \cdot 0$ \\
\hline \multirow{4}{*}{$\begin{array}{l}\text { (B) Active } \\
\text { Glaucoma } \\
\text { (Case 2) }\end{array}$} & 0 & $15 \cdot 00$ & 2160 & 144 & 144 \\
\hline & 1 & $14 \cdot 96$ & 2150 & $143 \cdot 7$ & 135 \\
\hline & 2 & $14 \cdot 85$ & 2135 & $143 \cdot 8$ & 133 \\
\hline & 7 & $14 \cdot 39$ & 2083 & $144 \cdot 8$ & 139 \\
\hline
\end{tabular}

\section{Summary}

(1) The correlation of the systemic and intra-ocular effects of a single dose of $250 \mathrm{mg}$. Diamox shews in almost every subject (both normal and glaucomatous) in the first $2 \mathrm{hrs}$, an initial fall in intra-ocular pressure which coincides with a fall in serum sodium, and an increased rate of excretion of urine and of urinary sodium and potassium.

(2) Glaucomatous patients excreted a slightly smaller volume of urine and smaller amounts of sodium and potassium than did normal subjects in the 7-hr test period after Diamox.

(3) A comparison of the cumulative increases in urinary output caused by Diamox above the " expected output " also confirms that a particularly low increase in sodium excretion occurs in glaucomatous subjects.

(4) The significance of the fall in serum sodium is discussed in relation to the depletion of water and sodium from the body.

Our thanks are due to Dr. T. Hanley for helpful criticism and advice, and to Messrs. Lederle for a supply of Diamox.

\section{REFERENCES}

BeCKer, B. (1955). Amer. J. Ophthal., 39, Suppl. (Feb., pt. 2), p. 177.

CampBell, D. A. (1955). Trans. ophthal. Soc. U.K., 75, 241.

C, Gloster, J., and Tonks, E. L. (1955). British Journal of Ophthalmology, 39, 193.

Counihan, T. B., Evans, B. M., and Milne, M. D. (1954). Clin. Sci., 13, 583.

Gloster, J., and PerkIns, E. S. (1955). British Journal of Ophthalmology, 39, 647.

Hanley, T., and PlatTs, M. M. (1956). J. clin. Invest., 35, 20.

Hofbauer, K., Kaindl, F., and ReInhardt, F. (1955). Wien. Z. inn. Med., 36, 93.

LANGHAM, M. (1955). Lancet, 1, 951.

LEPRI, G., and ANDREANI, D. (1954). Arch. Ottal., 58, 313.

LeYDHeCKer, W., and Helferich, E. (1955). Klin. Mbl. Augenhèilk., 126, 323.

MAREN, T. H., Ash, V. I., and BAILey, E. M. (1954). Bull. Johns Hopk. Hosp., 95, 244.

MAYER, E., and WADSWORTH, B. C. (1954). Ibid., 95, 199.

, Wadsworth, B. C., YAle, E. K., and Alonso, L. G. (1954). Ibid., 95, 99.

VERNEY, E. B. (1929). Lancet, 1, 539.

WeInstein, P. (1950). Amer. J. Ophthal., 33, 1442. 